\title{
Experimental Method to Quantify the Leakage Currents of Solar Cells from Current Density-Voltage Characteristics
}

\author{
K. Mahi ${ }^{1,2, *,}$, H. Aït-Kaci ${ }^{2}$ \\ ${ }^{1}$ Department of Physics, Faculty of Sciences of the Matter, University of Tiaret, BP P 78 Zaaroura, Tiaret, Algeria \\ ${ }^{2}$ Laboratory of Plasma Physics, Conductor Materials and their Applications, Faculty of Physics, Oran University of \\ Sciences and Technology Mohamed Boudiaf USTO-MB, BP1505 Oran, Algeria
}

(Received 21 June 2021; revised manuscript received 20 October 2021; published online 25 October 2021)

\begin{abstract}
To ameliorate the function and performance of photovoltaic and thermo-photovoltaic systems and cells, it is important to comprehend the physical properties of their components and transport processes occurring within their structures. A correct analysis of the current density-voltage behavior of a cell is then necessary. Cells often exhibit a non-ideal behavior due to parasitic effects attributed to the so-called series and shunt resistances. In this case, the extraction of cell parameters like reverse saturation current and ideality coefficient, which can give valuable information about charge transport mechanisms responsible for the currents in the cell, becomes quite difficult. In this work, to avoid mathematical and numerical complexity in the analysis of a current density-voltage $(J-V)$ characteristic of a device, we propose a simple experimental method for using such characteristics, quantify the leakage currents characterizing a device and correct the experimental $J$ - $V$ data. The results obtained from our method are largely in compliance with the theoretical $J$ - $V$ characteristics.
\end{abstract}

Keywords: Solar cell model, Transport mechanisms, Parameter extraction, Photocurrent, Ideality coefficient, Shunt conductance.

\section{INTRODUCTION}

Electronic and optoelectronic devices represent different types of designs (structures), ranging from a simple metal semiconductor contact (Schottky junction) or $p$ - $n$ homojunction to more complex structures such as heterojunctions, superlattices and quantum wells. However, whatever the design of the component, the $p$ - $n$ junction remains the basic structure. In order to optimize the operation and performance of these devices, it is necessary to know the physical phenomena and the transport processes.

Among the characterization techniques used for solar cells, the dark current density-voltage $(J-V)$ measurements or under illumination condition are of great utility for the extraction of electrical parameters such as ideality coefficient $(m)$, reverse saturation current density $\left(J_{s}\right)$, parallel resistance $\left(R_{s h}\right)$, series resistance $\left(R_{s}\right)$, and photocurrent $\left(J_{p h}\right)$. These parameters are of great importance, since they can give the first idea of the conduction processes occurring across the interface of the structure. They also inform about the solar cells performances and the possibilities to optimize them.

Many different techniques have been suggested in the literature to extract these parameters from measurements of current density-voltage curves under illumination [1-8]. If we take the example of the standard method, it is widely used to extract the $m$ and $J_{s}$ parameters of a solar cell from the analysis of the linear part of the current density-voltage curve. This method uses the logarithmic transformation of the $J-V$ characteristic based on the Shockley equation.

A number of methods were previously mentioned which use new equations or functions mathematically obtained from a modification of the expression of the $J-V$ characteristic of a solar cell [6-9]. Sometimes, these types of methods use a one-exponential solar cell model. Other methods use numerical operations on the current density-voltage data [10,11]. Methods using derivation or integration operations on the $J-V$ data are punctuated by several numerical errors [12]. They are also very sensitive to the environmental noise during the measurement, and it cannot be used if there is the presence of excess currents due to surface or bulk defects. Another important parameter which can influence the results for $m$ and $J_{s}$ is the applied step voltage, particularly in the case of techniques using derivation or integration procedures [12].

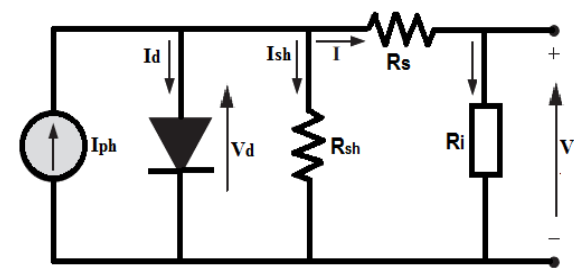

Fig. 1 - Equivalent circuit of a $p-n$ junction solar cell model

Based on these reports and in order to obtain the correct approximate values, we proposed a new and purely experimental technique for analyzing the current density-voltage curves of solar cells and numerically extracting the intrinsic solar cell parameters (i.e., ideality coefficient, reverse saturation current density and parallel conductance). The method suggested in the present paper is based on the use of additional variable resistors installed in parallel with the sample

\footnotetext{
*khaled.mahi@univ-tiaret.dz

† mahikhalidou@yahoo.fr
} 
studied (see Fig. 1). Using our proposed method, a set of parameters was derived indirectly, but with much more precision.

\section{PROPOSED METHOD FOR EXTRACTING THE SHUNT RESISTANCE}

\section{$2.1 \quad J-V$ Modeling with Leakage Currents}

Exceptionally in some materials whose technology was controlled such as silicon, components may have defects related to growth and deposition techniques of layers or to the elaboration processes. These defects cause deviations from the ideal current density-voltage characteristic variations. These deviations are modeled by excess currents (leakage currents), generally due to surface or bulk defects.

Leakage currents, which appear at low forward or reverse polarization, are generally modeled by a resistance parallel to the junction (Fig. 2) $[13,14]$. The value of this parameter $\left(R_{s h}\right)$ gives information on the quality of a solar cell and its performance. Sometimes, the value of $R_{s h}$ is deduced by extrapolating the linear part of the inverse $J$ - $V$ characteristic [15]. When a solar cell has low currents, as is the case with wide band gap semiconductor devices, this method remains difficult to apply because of noise in measurements at low polarizations.

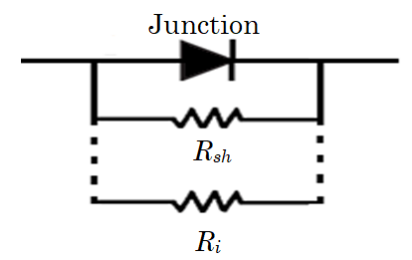

Fig. 2-Schematic representation of leakage currents in a junction-based solar cell

In the following paragraphs of this paper, we have proposed an experimental method to quantify the leakage currents of solar cells. In this method, we use forward current density-voltage variations, because measurements are easier and currents are detected with minimal noise, even with medium precision measuring devices (of the order of $\mu \mathrm{A}$ ).

\subsection{Method Development}

As mentioned above, our proposed method for determining the shunt resistance consists in imposing different additional leakage currents by connecting resistors in parallel with the sample studied. The resulting currents are added to the currents of the solar cell. An empirical expression for the current density in a solar cell is written in the following form [15-20]:

$$
J=J_{p h}-J_{S}\left(e^{\frac{\beta}{m} V}-1\right)-\frac{V}{R_{s h}},
$$

where $V$ is the applied voltage, $J$ is the current density, $J_{p h}$ is the photogenerated current, $J s$ is the reverse saturation current density, $m$ is the ideality coefficient, and $R_{s h}$ is the shunt resistance. The term $\beta=q / k T$ represents the thermal voltage. If at low polarization the solar cell has significant leakage characterized by the shunt resistance $R_{s h}$, the term $V / R_{s h}$ becomes dominant, and Eq. (1) is reduced to a simple ohm law:

$$
J=J_{p h}-\frac{V}{R_{s h}} .
$$

For a fixed voltage $V$, the use of additional variable resistors $R_{i}$ installed in parallel with the sample studied implies an augmentation in the current density. In this case, Eq. (2) is written as:

$$
\frac{J_{p h}-J_{i}}{V}=\frac{1}{R_{s h}}+\frac{1}{R_{i}} .
$$

Equation (3) shows that conductance $G_{i}=\left(J_{p h}-J_{i}\right) / V$ varies linearly with the inverse of additional variable resistors. The plot $G_{i}=f\left(1 / R_{i}\right)$ should give a slope equal to 1 , whatever the value of resistance $R_{i}$ used. The $y$ intercept directly gives the leakage resistance $R_{s h}$ characteristic of a solar cell. Consider a set of $N$ measured values of the voltage $V_{i}$. The calculation of the mean of the values obtained for $R_{s h}$ provides a sufficiently accurate value from the following expression:

$$
R_{s h}=\frac{\sum_{i=1}^{N} R_{s h i}}{N} .
$$

Equation (4) can give a good result only under the following conditions:

1. A sufficiently large number of parallel resistors with values close to the real value of $R_{s h}$ of a solar cell. This can ensure a minimum of errors in the actual value sought.

2 . The variations in $G_{i}=f\left(1 / R_{i}\right)$ should be calculated in the polarization domain, where the term of leakage current $V / R_{s h}$ is sufficiently larger that the exponential term.

Condition (2) can be verified by examining the current density-voltage characteristic on a logarithmic scale: $\log J=f(\log V)$.

\section{RESULTS ON A DARK $J-V$ SOLAR CELL CHARACTERISTIC}

In order to test the validity of our method, a current density-voltage characteristic corresponding to a single exponential expression and the term of leakage current (Eq. (1)) is simulated in the forward direction. The values used for $J_{s}$ and $m$ are $10^{-10} \mathrm{~A} / \mathrm{cm}^{-2}$ and 1.5 , respectively. The solar cell supposed has a parallel resistance (shunt) of $1 \mathrm{M} \Omega$. Leakage currents are put in parallel with the sample; we suppose that additional shunt resistances vary from 0.25 to $2 \mathrm{M} \Omega$ in steps of $250 \mathrm{k} \Omega$. The simulation results in semi-logarithmic and logarithmic scales are shown in Fig. 3 and Fig. 4, respectively.

Using the simulated characteristics shown in Fig. 3, and for variable resistances from 0.25 to $2 \mathrm{M} \Omega$, the extracted graph of $G_{i}$ versus $1 / R_{i}$ is given in Fig. 5. In the voltage range, where the current density-voltage characteristic deviates from linearity, the result is a straight line for all used additional variable resistors. 
The calculation of the slope for all lines gives a mean value equal to 1.01, and the ordinate intercept gives an extracted value of $R_{s h}=0.99 \mathrm{M} \Omega$.

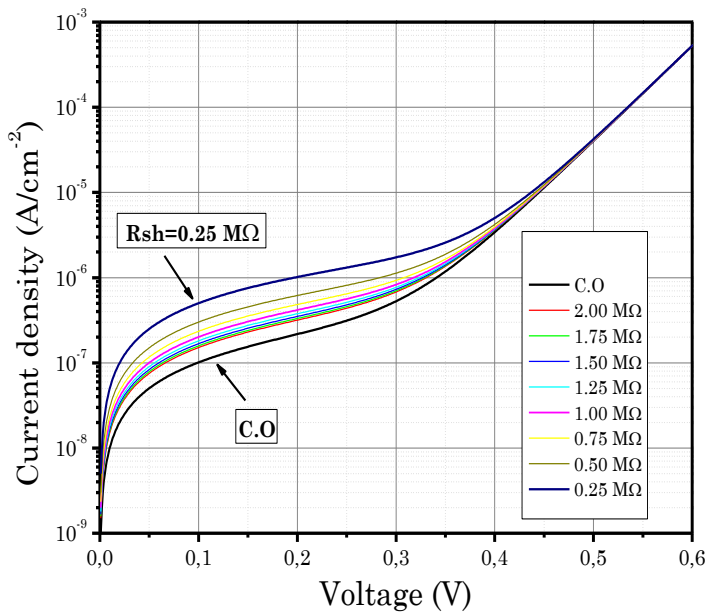

Fig. 3 - Dark $J-V$ characteristics of a solar cell simulated by Eq. (3) in semi-logarithmic scale

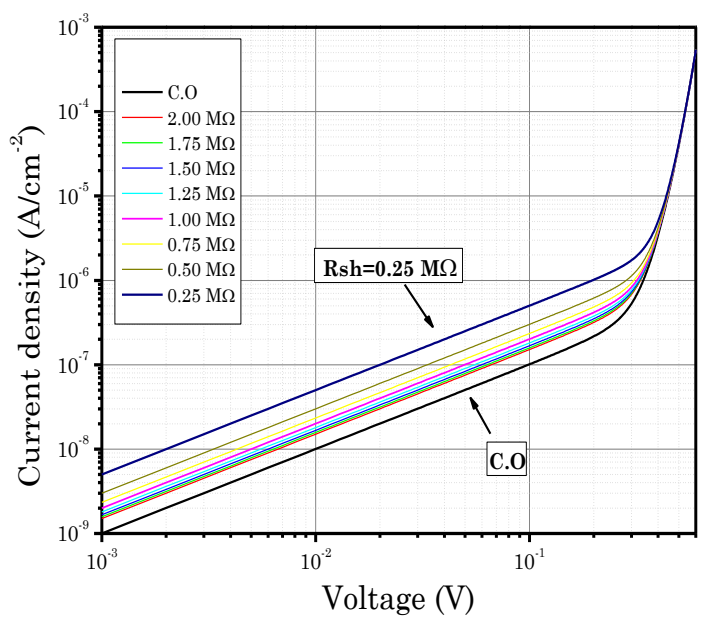

Fig. 4 - Dark $J-V$ characteristics of a solar cell simulated by Eq. (3) in logarithmic scale, $\log J=f(\log V)$

It is clear that the parallel resistance evaluated with the proposed technique is very close to those used for the simulation. This situation is valid for any value of the chosen variable resistance. The choice of the value of this resistance does not matter.

\section{COMPARISON OF THE EFFECTS OF $m$ AND $J_{s}$ ON THE PROPOSED METHOD}

This comparison allows us to examine the extracted values of the shunt resistance for different values of the reverse saturation current density $J_{s}$ and the ideality coefficient $m$. For the calculations, we have chosen the following values for $m$ and $J_{s}$ :

a-We fixed the value of the ideality coefficient $(m=1.5)$ and for the values of the reverse saturation current density $J_{s}$ chose: $10^{-9}, 10^{-10}, 10^{-12} \mathrm{~A} / \mathrm{cm}^{-2}$.

b - We fixed the value of the reverse saturation current density $\left(J_{s}=10^{-10} \mathrm{~A} / \mathrm{cm}^{-2}\right)$ and for the ideality coefficient $m$ chose: $1.0,1.5$ and 2.0 .

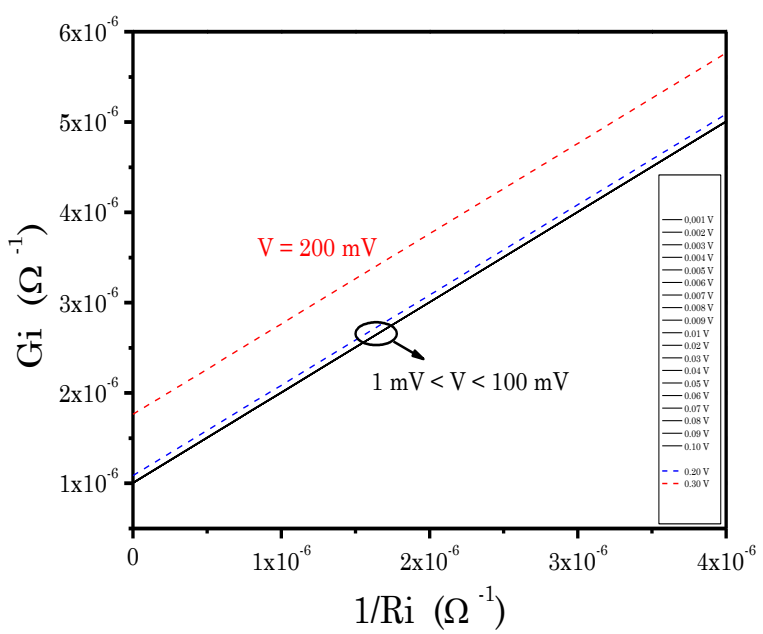

Fig. 5 - The variation of conductance $G_{i}$ as a function of the inverse resistance $\left(1 / R_{i}\right)$

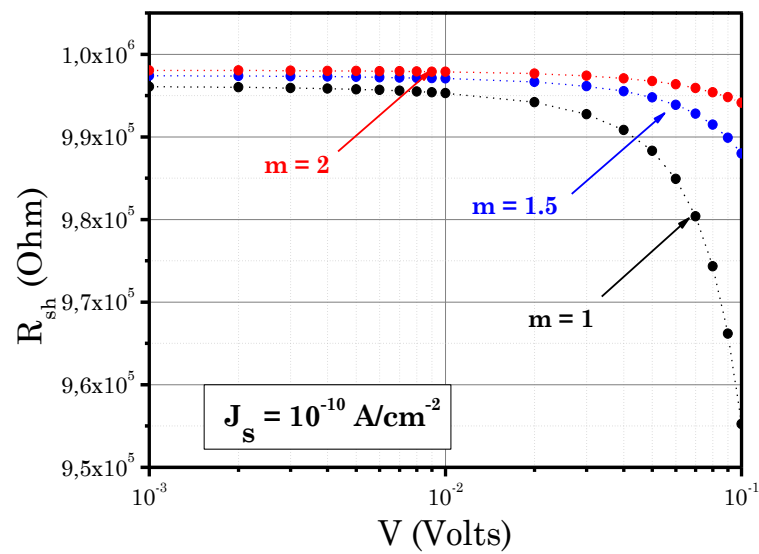

Fig. 6 - Comparison of the extracted values of $R_{s h}$ for different values of the ideality coefficient

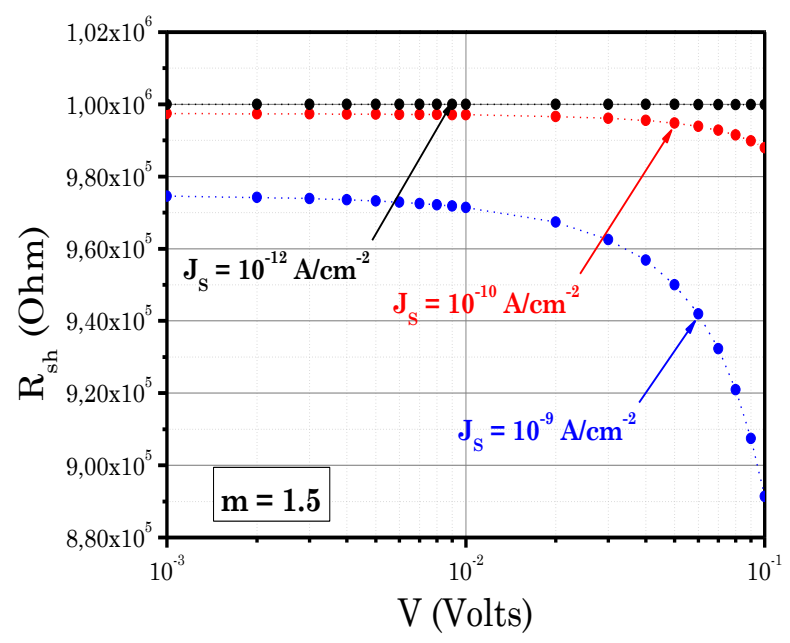

Fig. 7 - Comparison of the extracted values of $R_{s h}$ for different values of the reverse saturation current density

In Fig. 6 and Fig. 7, we show the variation of the shunt resistance $R_{s h}$ as a function of the applied voltage $V$ plotted from the lines $J_{p h}-J_{i} / V=f\left(1 / R_{i}\right)$ for both cases $\mathbf{a}$ and $\mathbf{b}$.

According to Fig. 6 and Fig. 7, this comparison clearly shows a small difference in the results of the 
shunt resistance obtained for the two cases $\mathbf{a}$ and $\mathbf{b}$. When the reverse saturation current density is fixed, the value of the ideality coefficient $m$ about 2 gives a more correct result of $R_{s h}$ than the value close to 1 . On the other hand, in case $\mathbf{b}$, when the ideality coefficient is constant, we deduce that when the reverse saturation current density diminishes, the shunt resistance obtained tends to a more exact value.

\section{CONCLUSIONS}

By simple modeling based on phenomenological (empirical) equations for currents passing through a $p$ $n$ junction based cell, we have highlighted the influence of undesirable currents on the behavior of solar cells.

The results of this simulation allowed us to draw conclusions about the difficulties in using experimental current density-voltage data, particularly in the case of very leaky solar cells. It is therefore necessary to take into account all additional currents in order to be able to exploit the characteristics and obtain a correct interpretation concerning charge transport in solar cells. We have therefore developed a simple experimental technique to quantify leakage currents and eliminate them in order to extract the real characteristics of a $p$ - $n$ junction solar cell. Contrary to what is done in general, this method uses the $J-V$ variations in the passing direction instead of the blocked direction, for the simple reason that forward currents are important and easy to measure.

\section{ACKNOWLEDGEMENTS}

The authors thank Dr. Bousmaha Mohamed from the Department of Physics, Faculty of Sciences of the Matter, University of Tiaret, Algeria, for help.

\title{
REFERENCES
}

1. C. Kumar, T. Dharma Raj, M. Premkumar, T. Dhanesh Raj, Optik 223, 165277 (2020)

2. M. Hebali, M. Bennaoum, H.A. Azzeddine, B. Ibari, M. Benzohra, D. Chalabi, J. Nano- Electron. Phys. 12 , 06033 (2020).

3. L. Shu-xian, G. Ting-ting, D. Cun-jiao, Sol. Energy 119, 179 (2015)

4. G. Xiankun, C. Yan, H. Jianjun, X. Guangyin, Y. Yongchang, Energy Convers. Manage. 127, 443 (2016).

5. H.S. Moreira, J.L.S. Silva, M.V. Gomes dos Reis, D.B. Mesquita, B.H.K. de Paula, M.G. Villalva, Renew. Energy, 164, 58 (2021).

6. K. Mahi, B. Messani, H. Ait-kaci, J. Nano- Electron. Phys. 11, 04030 (2019)

7. S. Yadir, S. Assal, A. El Rhassouli, M. Sidki, M. Benhmida, Opt. Mater. 36, 18 (2014).

8. A.M. Humada, M. Hojabria, S. Mekhilef, H.M. Hamada, Renew. Sustain. Energy Rev. 56, 494 (2016).

9. E. Erdoğana, M. Kundakçı, Physica B 506, 105 (2017).

10. L.E.P. Chenche, O.S.H. Mendoza, E.P.B. Filho, Renew. Sus tain. Energy Rev. 81, 2823 (2018).

11. T.R. Ayodele, A.S.O. Ogunjuyigbe, E.E. Ekoh, Sustain. Energy Technol. Assessments 13, 51 (2016).

12. N. Kavasoglu, A.S. Kavasoglu, S. Oktik, Curr. Appl. Phys. 9, 833 (2009).

13. P.M. Lal, S.N. Singh, Sol. Energy Mater. Sol. C. 91, 137 (2007).

14. E.E. Van Dyk, E.L. Meyer, Renew. Energy 29, 333 (2004).

15. V. Gopal, S. Gupta, Infrared Phys. Technol. 45, 265 (2004).

16. A. Ferhat-Hamida, Z. Ouennoughi, A. Hoffmann, R. Weiss, Solid-State Electron. 46, 615 (2002).

17. R. Navabi, S. Abedi, S.H. Hosseinian, R. Pal, Energy Convers Manage 89, 497 (2015).

18. Z. Chen, Y. Lin, L. Wu, S. Cheng, P. Lin, Energy Convers. Manage. 226, 113521 (2020).

19. A.M. Humada, S. Darweesh, K.G.Y. Mohammed, M. Kamil, S.F. Mohammed, N.K. Kasimh, T.A. Tahseen, O.I. Awad, S. Mekhilef, Sol. Energy 199, 742 (2020).

20. H. El Achouby, M. Zaimi, A. Ibral, E.M. Assaid, Energy Convers. Manage. 177, 258 (2018).

\section{Експериментальний метод кількісної оцінки струмів витоку сонячних елементів за залежностями густини струму від напруги}

\author{
K. Mahi1,2, H. Aït-Kaci² \\ ${ }^{1}$ Department of Physics, Faculty of Sciences of the Matter, University of Tiaret, BP P 78 Zaaroura, Tiaret, Algeria \\ ${ }^{2}$ Laboratory of Plasma Physics, Conductor Materials and their Applications, Faculty of Physics, Oran University of \\ Sciences and Technology Mohamed Boudiaf USTO-MB, BP1505 Oran, Algeria
}

\begin{abstract}
Для поліпшення фуннцій і продуктивності фотоелектричних та термодотоелектричних систем та елементів важливо розуміти фрізичні властивості їх компонентів та транспортні процеси, що відбуваються в їх структурах. Для цього необхідний правильний аналіз залежності густини струму від напруги в елементі. Елементи часто демонструють неідеальну поведінку через паразитні ефекти, пов'язані з так званими послідовним та шунтуючим опорами. У цьому випадку вилучення таких параметрів елементу, як зворотний струм насичення та коефіціент ідеальності, які можуть дати цінну інформацію про механізми перенесення заряду, відповідальні за струми в елементі, стає досить складним. У роботі, щоб уникнути математичної та числової складності при аналізі залежності густини струму від напруги (J-V), характерної для пристрою, ми пропонуемо простий експериментальний метод використання таких характеристик, кількісну оцінку струмів витоку, що характеризують пристрій, та виправлення експериментальних даних залежності $J$ - $V$. Результати, отримані нашим методом, значною мірою відповідають теоретичним залежностям $J-V$.
\end{abstract}

Ключові слова: Модель сонячного елементу, Транспортні механізми, Вилучення параметрів, Фотострум, Коефіціент ідеальності, Шунтова провідність. 